\title{
Higher body fatness in intrauterine growth retarded juvenile pigs is associated with lower fat and higher carbohydrate oxidation during ad libitum and restricted feeding
}

\author{
Ricarda Krueger · Michael Derno · Solvig Goers - Barbara U. Metzler-Zebeli • \\ Gerd Nuernberg $\cdot$ Karen Martens $\cdot$ Ralf Pfuhl $\cdot$ Constanze Nebendahl · \\ Annette Zeyner $\cdot$ Harald M. Hammon $\cdot$ Cornelia C. Metges
}

Received: 17 June 2013/Accepted: 18 July 2013/Published online: 2 August 2013

(c) The Author(s) 2013. This article is published with open access at Springerlink.com

\begin{abstract}
Purpose A thrifty energy metabolism has been suggested in intrauterine growth restricted (IUGR) offspring. We characterized energy metabolism and substrate oxidation patterns in IUGR pigs in response to food restriction (FR) and refeeding (RFD).

Methods Female pigs with low (L; $1.1 \mathrm{~kg} ; n=20)$ or normal birth weight $(\mathrm{N} ; 1.5 \mathrm{~kg} ; n=24)$ were fed ad libitum after weaning. Half of $\mathrm{L}$ and $\mathrm{N}$ pigs were food restricted (R; LR, NR) from days 80 to 100 (57\% of ad libitum) and refeed from days 101 to 131, while the remaining pigs were fed ad libitum (control, C). Using indirect calorimetry, carbohydrate and fat oxidation (COX, FOX), energy expenditure (EE) and balance (EB), resting metabolic rate (RMR) [all related to $\mathrm{kg}$ body weight ${ }^{0.62}$ $(\mathrm{BW})$ ] and RQ were determined at 4 days before (day 76) and after (day 83) beginning of FR, 4 days before (day 97)
\end{abstract}

Electronic supplementary material The online version of this article (doi:10.1007/s00394-013-0567-x) contains supplementary material, which is available to authorized users.

R. Krueger · M. Derno · S. Goers · B. U. Metzler-Zebeli

K. Martens - C. Nebendahl · H. M. Hammon .

C. C. Metges ( $\square)$

Institute of Nutritional Physiology 'Oskar Kellner',

Leibniz Institute for Farm Animal Biology (FBN),

18196 Dummerstorf, Germany

e-mail: metges@fbn-dummerstorf.de

Present Address:

B. U. Metzler-Zebeli

Clinic for Swine, University of Veterinary Medicine Vienna,

1210 Vienna, Austria

\section{G. Nuernberg}

Institute of Genetics and Biometry, Leibniz Institute for Farm

Animal Biology (FBN), 18196 Dummerstorf, Germany and after (day 104) end of FR and 25 days after beginning of RFD (day 125). Body fat and muscle weights were determined at day 131 .

Results In spite of higher relative food intake (FI), BW was lower in L pigs. In L pigs, physical activity was lower at age 76 and 83 days compared to N pigs. IUGR did not affect EE or RMR, but resulted in higher COX and lower FOX, causing greater and earlier onset of fat deposition. During FR, EE and RMR of R pigs dropped below that of $\mathrm{C}$ pigs, and BW gain was delayed by $30 \%$ irrespective of birth weight. In response to FR, COX decreased and FOX increased. During FR, in LR pigs FOX was $\sim 50 \%$ of that in NR pigs. After 4 days, but not 25 days of RFD, EB and fat synthesis were higher in pigs previously subjected to FR, indicating early catch-up fat. In R pigs, BW and the abdominal fat proportion were lower at 131 days.

Conclusions Differences in food intake and substrate oxidation pattern, but not in EE and RMR, between L and $\mathrm{N}$ pigs were reflected in higher body fat proportions but lower body and muscle weights in L pigs. Refeeding

\section{R. Pfuhl}

Institute of Muscle Biology and Growth, Leibniz Institute for Farm Animal Biology (FBN), 18196 Dummerstorf, Germany

\section{A. Zeyner}

Chair of Animal Nutrition, University of Rostock,

18059 Rostock, Germany

Present Address:

A. Zeyner

Chair for Nutritional Physiology and Animal Nutrition, Martin Luther University Halle-Wittenberg, 06120 Halle, Germany 
following FR was initially associated with increased FI, a more positive EB and a more intense stimulation of fat synthesis which did not persist after 25 days of refeeding.

Keywords Energy expenditure - Low birth weight piglets - Fat oxidation - Food restriction .

Fuel selection · Plasma NEFA

\section{Introduction}

Intrauterine growth retardation (IUGR) has been recognized as a condition which increases the propensity for adult metabolic disorders such as diabetes type 2 or obesity $[1,2]$. It has been suggested that catch-up growth following IUGR is characterized by a disproportionately higher rate of fat gain and that this is in part driven by suppressed thermogenesis [3]. It has been shown that a greater weight gain and fat mass early in life after thinness at birth are risk factors for obesity $[4,5]$. The pig is increasingly used as a biomedical animal model due to its similarity to human physiology [6, 7]. In pigs, $20 \%$ of the littermates show naturally occurring IUGR leading to reduced postnatal and muscle growth and increased body fatness during puberty and young adulthood [8-13]. However, whether IUGR is associated with alterations of components of energy expenditure (EE) or substrate oxidation pattern during early postnatal life, to our knowledge, is not known.

The ability to adjust nutrient oxidation to the availability of fuels is an important mechanism for organisms to adapt to differing physiological and nutritional conditions. Temporary food restriction (FR) or starvation are associated with decreased EE and resting metabolic rate (RMR), as well as increased fat oxidation (FOX) and decreased carbohydrate oxidation (COX) [14-16]. However, it is a matter of debate whether a period of energy restriction can lead to a faster rate of fat recovery relative to lean tissue recovery during realimentation [17].

We therefore investigated in a porcine model whether IUGR individuals as compared to age-matched normal birth weight (BiW) littermates show lower EE, RMR, and FOX. We further hypothesized that FR in IUGR pigs (1) impairs their BW development and stimulates their propensity for fat deposition during refeeding (RFD), (2) stimulates food intake (FI) during RFD and (3) leads to disproportionately altered muscle weights and body composition after a period of RFD. Thus, we characterized components of energy metabolism and determined withinday changes of fuel selection in response to age, FR and RFD in normal BiW and IUGR pigs. In an attempt to link EE to the metabolic level, we also monitored the course of plasma NEFA concentration.

\section{Methods}

Animals and experimental design

The experimental procedures were carried out in accordance with the German Animal Protection regulations and were approved by the relevant authorities of the Land Mecklenburg-Vorpommern, Germany (Landesamt für Landwirtschaft, Lebensmittelsicherheit und Fischerei, Mecklenburg-Vorpommern; permission no. LALLF M-V/ TSD/7221.3-1.1-049/09).

Seventeen German Landrace litters (2nd to 4th parity sows; mean litter size $n=15 \pm 0.6$; mean piglet weight $=1.4 \pm 0.02 \mathrm{~kg}$ ) were used. Pairs of female littermates were selected of which one piglet had a low (L; $0.8-1.2 \mathrm{~kg} ; n=20)$ and the other piglet had normal $(\mathrm{N}$; $1.3-1.8 \mathrm{~kg} ; n=24)$ BiW. Low BiW was defined as having a BiW less than the lower quartile of the average litter BiW in our pig breeding facility [18]. The experiment was performed in 4 blocks of 12 pigs each, and each block contained all groups. Four pigs had to be removed from the experiment due to sudden death, illness or insufficient FI.

Piglets were suckled by their dam. Post-weaning diets were formulated to supply energy and nutrients at or above recommendations [19] (Table 1). After weaning at 28 days of age, piglets were fed ad libitum a diet formulated for the post-weaning period ('Baby Crisb,' Bergophor Hohburg Mineralfutter GmbH, Hohburg, Germany) plus oat flakes (Holstenmühle W. Smidt \& Co. KG, Lübeck, Germany) and sucrose (Nordzucker, Braunschweig, Germany) until day 79 of age. From day 80 of age onwards, the pigs received a grower diet ('Vormast CaFo TOP,' Trede und von Pein GmbH, Itzehoe, Germany) plus oat flakes and sucrose (Online Resource 1; Table 1).

At 79 days of age, we randomly selected half of the $\mathrm{N}$ and $\mathrm{L}$ pigs as control (C) groups which were continued on ad libitum feeding (NC, $n=12$; LC, $n=10$ ) until the age of 130 days. The remaining pigs were food restricted (R) (NR, $n=12$; LR, $n=10)$ at a target energy intake (EI) level of $60 \%$ of the control group for 21 days before they were returned to ad libitum feeding which was continued until the age of 130 days (Online Resource 2). Piglets were transferred to single pens $(2.40 \times 1.40 \mathrm{~m}$; with slatted floor) to allow for individual FI measurements until the end of the experiment. Room temperature and relative humidity were $22{ }^{\circ} \mathrm{C}$ and $65 \%$, respectively, and light was on between 0600 and 1900 h. Pigs were fed twice daily with $50 \%$ of their daily allowance at 0800 and $1500 \mathrm{~h}$, respectively. Water was available ad libitum from nipple drinkers. 
Table 1 Diet components, dry matter (DM), calculated crude nutrient composition, and metabolizable energy (ME), classified according to age of pigs

\begin{tabular}{|c|c|c|c|c|}
\hline & \multicolumn{4}{|c|}{ Age (day) } \\
\hline & $28-41$ & $42-79$ & $80-130$ & $80-100$ (R pigs) \\
\hline \multicolumn{5}{|c|}{ Diet components (weight $\%$ of daily food allowance) } \\
\hline Starter feed ${ }^{\mathrm{a}}$ & 50 & 46.5 & - & - \\
\hline Grower feed ${ }^{\mathrm{b}}$ & - & - & 68.5 & 100 (= $825 \mathrm{~g} /$ day $)$ \\
\hline Oat flakes ${ }^{c}$ & 30 & 33.8 & 20.7 & - \\
\hline Sucrose $^{\mathrm{d}}$ & 20 & 19.7 & 10.8 & - \\
\hline $\mathrm{DM}(\%)$ & 98 & 98 & 98 & 98 \\
\hline \multicolumn{5}{|c|}{ Crude nutrients $(\mathrm{g} / \mathrm{kg})$} \\
\hline Crude ash & 35 & 34 & 44 & 57 \\
\hline Crude protein & 162 & 159 & 165 & 197 \\
\hline Crude fat & 94 & 92 & 38 & 32 \\
\hline Carbohydrates & 604 & 612 & 641 & 576 \\
\hline Crude fiber & 16 & 16 & 39 & 51 \\
\hline Starch & 314 & 330 & 440 & 447 \\
\hline Sugar & 278 & 270 & 148 & 57 \\
\hline $\mathrm{ME}^{\mathrm{e}}(\mathrm{MJ} / \mathrm{kg} \mathrm{DM})$ & 16.9 & 16.9 & 15.2 & 14.7 \\
\hline
\end{tabular}

a 'Baby Crisb,' Bergophor, Hohburg Mineralfutter GmbH, Hohburg, Germany

b 'Vormast CaFo TOP,' Trede und von Pein GmbH, Itzehoe, Germany; during food restriction diet was devoid of sugar and oat flakes

${ }^{c}$ Holstenmühle W. Smidt \& Co. KG, Lübeck, Germany

d Nordzucker, Braunschweig, Germany

${ }^{\text {e }}$ Calculated according to GfE (2008): ME (MJ/kg DM) = $0.021503 \times$ crude protein $(\mathrm{g} / \mathrm{kg} \mathrm{DM})+0.032497 \times$ crude fat $(\mathrm{g} / \mathrm{kg}$ $\mathrm{DM})-0.021071 \times$ crude fiber $(\mathrm{g} / \mathrm{kg} \mathrm{DM})+0.016309 \times \operatorname{starch}(\mathrm{g} / \mathrm{kg}$ $\mathrm{DM})+0.014701 \times$ organic residue $(\mathrm{g} / \mathrm{kg} \mathrm{DM})$

Body weight, food intake and food analysis

The BW (kg) and FI (g/kg BW) were averaged weekly. $\mathrm{BW}, \mathrm{BW}$ gain, FI and food conversion ratio (FCR) on defined days or within a period were calculated by polynomial fitting up to 9th (BW) or 10th (FI) order (Table Curve 2D, version 5.01, Systat Software GmbH, Erkrath). Food intake for $\mathrm{R}$ pigs was fitted separately before and after FR.

Proximate nutrient analysis of oat flakes and commercial food was performed at the Chair of Animal Nutrition, University of Rostock, according to standardized methods [20]. Dry matter was determined after 3-h drying at $105^{\circ} \mathrm{C}$ (method no. 3.1). Crude fiber was analyzed by FOSS analyzer (Fibertec ${ }^{\mathrm{TM}}$ 2010, FOSS GmbH, Rellingen, Germany) and crude fat according to the Soxhlet procedure (method no. 5.1.1). Crude protein and ash were measured using Dumas combustion (vario MAX, Elementar Analysensysteme GmbH, Hanau, Germany). Sugars were analyzed gravimetrically by the Fehling method, and starch determination was based on glucose analysis by HPLC on a HPX $-87 \mathrm{C}$ column (BIORAD) protected with a $\mathrm{CO}_{3}{ }^{-}$cartridge (BIORAD) after enzymatic degradation with $\alpha$-amylase and amyloglucosidase (TERMAMYL, Novo Nordisk A/S, Denmark).

Indirect calorimetry measurements, procedures and calculations

To determine components of energy metabolism, opencircuit indirect calorimetry was used. The chambers $\left(1.5 \mathrm{~m}^{3}\right)$ were air-conditioned to maintain a constant temperature of $22{ }^{\circ} \mathrm{C}$ at $\sim 70 \%$ relative humidity. The air flow through the chambers was $7 \mathrm{~m}^{3} / \mathrm{h}$. Concentrations of $\mathrm{CO}_{2}$ and $\mathrm{O}_{2}$ in chamber air samples were analyzed by infrared absorption (UNOR 610, MAIHAK AG, Hamburg, Germany) and paramagnetically (OXYGOR 610, MAIHAK AG, Hamburg, Germany), respectively. Physical activity (PA) was monitored with infrared detectors (Steinel, Herzebrock-Clarholz, Germany). When the infrared beam was interrupted by the animal for $1 \mathrm{~s}$, ten impulses of PA were recorded. This allowed the calculation of total PA during each stay in the calorimetric chamber.

Calorimetric measurements were performed over $23 \mathrm{~h}$ each at 5 consecutive time points (and ages) during the experiment: 4 days prior to FR (T1, 76 days), on day 4 (T2a, 83 days) and day 18 (T2b, 97 days) of FR, and on day 4 (T3a, 104 days) and day 25 (T3b, 125 days) of RFD (Online Resource 2). After overnight food withdrawal, calorimetric measurements were started at $0830 \mathrm{~h}$ and pigs were fed half of the daily feed allowance at 0930 and 1600 h. Food access was denied between $1800 \mathrm{~h}$ until the next morning $0800 \mathrm{~h}$ when measurements were terminated. Light was turned off from $1900 \mathrm{~h}$ until $0600 \mathrm{~h}$. Pigs were weighed directly before and after measurements or biweekly when no calorimetric measurement was performed. Water was available ad libitum. Total oxygen consumption $\left(V_{\mathrm{O}_{2}}\right)$ and $\mathrm{CO}_{2}$ production $\left(V_{\mathrm{CO}_{2}}\right)$ were measured every 6 min corresponding to 230 values per animal in $23 \mathrm{~h}$. Values were added up over $23 \mathrm{~h}$ and subsequently normalized to $24 \mathrm{~h}$ to calculate daily $\mathrm{EE}(\mathrm{kJ} / \mathrm{d})$ and 'net disappearance rates' of carbohydrates (COX, g/d) and lipids (FOX, g/d) from their respective metabolic pools (where 'disappearance' is largely oxidation) [21]:

$\mathrm{COX}=4.12 \times V_{\mathrm{CO}_{2}}-2.91 \times V_{\mathrm{O}_{2}}-2.33 \times m_{\text {urinary } \mathrm{N}}$

$\mathrm{FOX}=1.69 \times V_{\mathrm{O}_{2}}-1.69 \times V_{\mathrm{CO}_{2}}-2.03 \times m_{\text {urinary } \mathrm{N}}$

$\mathrm{EE}=3.91 \times V_{\mathrm{O}_{2}}+1.10 \times V_{\mathrm{CO}_{2}}-1.93 \times m_{\text {urinary }}$

where $V_{\mathrm{CO}_{2}}$ and $V_{\mathrm{O}_{2}}$ (in L/d) are 24-h values and $m_{\text {urinary } \mathrm{N}}$ $(\mathrm{g} / \mathrm{d})$ refers to the estimated urinary $\mathrm{N}$ excreted on the measurement day. Urinary $\mathrm{N}$ excretion was estimated 
based on published values measured under similar experimental conditions as in the present study [15, 2224]. Nitrogen excreted via urine corresponded to $40 \%$ of ingested $\mathrm{N}$, whereas during the RFD period (T3a and T3b; $\mathrm{R}$ pigs), it was estimated to be equivalent to $35 \%$ of ingested N. Estimated daily urinary $\mathrm{N}$ excretion served as basis to calculate protein disappearance rate $\left(\mathrm{P}_{\mathrm{dis}}\right)$, expressing the difference between $\mathrm{N}$ intake and urinary $\mathrm{N}$ excretion ( $\left.m_{\text {urinary } \mathrm{N}}\right)[21]$ :

$\mathrm{P}_{\text {dis }}=6.25 \times m_{\text {urinary } \mathrm{N}}$

The daily respiratory quotient (RQ) was calculated as 24-h production of $\mathrm{CO}_{2}$ (L) divided by 24-h consumption of $\mathrm{O}_{2}$ (L). Resting metabolic rate (RMR) as a measure of basal metabolic rate (or fasting heat production) was derived from the 10 lowest EE values over the 23-h measurement period that were averaged and normalized to $24 \mathrm{~h}$, reflecting energy metabolism due to basal metabolic rate and not due to FI, digestion of nutrients or PA. Energy expenditure due to $\mathrm{PA}\left(\mathrm{EE}_{\mathrm{PA}}\right)$ was calculated according to $0.9 \times 24-\mathrm{h} \mathrm{EE}$, 24-h RMR, assuming that the thermic effect of food is $\sim 10 \%$ of EE $[25,26]$. Energy balance (EB) was calculated by subtracting 24-h EE from daily energy intake (EI) in MJ ME. Daily COX, FOX, EE, EB and RMR were then expressed relative to metabolic BW $\left(\mathrm{kg} \mathrm{BW}^{0.62}\right)$ and $\mathrm{COX}$ additionally to the amount of FI ( $\left.\mathrm{g} / \mathrm{kg} \mathrm{BW}^{0.62} \mathrm{~kg} \mathrm{FI}^{-1}\right)$. As an indicator for efficiency of energy utilization, the $Q$ value was calculated for individual $\mathrm{N}$ and $\mathrm{L}$ pigs during ad libitum feeding as 24-h EE (MJ ME) divided by corresponding daily energy intake (MJ ME). The higher the $Q$ value, the higher the relative heat loss and the less energy was retained as body mass (protein accretion and/or fat deposition).

\section{Diurnal substrate oxidation pattern and plasma NEFA concentrations}

Individual amounts of COX and FOX were calculated for 6-min intervals [21]. Because $\mathrm{P}_{\text {dis }}$ was calculated per $\mathrm{d}$ based on literature values, it was divided in 6-min intervals. Then, COX, FOX and $\mathrm{P}_{\text {dis }}$ values were expressed as $\mathrm{g} / \mathrm{kg}$ $\mathrm{BW}^{0.62}(6 \mathrm{~min})^{-1}$ and transferred to the corresponding energetic values of carbohydrates $(17.2 \mathrm{~kJ} / \mathrm{g})$, fat $(38.9 \mathrm{~kJ} /$ g) and protein $(17.8 \mathrm{~kJ} / \mathrm{g})$, respectively [27]. The 6-min energetic values of the 3 macronutrients were added up to total $\mathrm{EE}_{6} \min \left[\mathrm{kJ} / \mathrm{kg} \mathrm{BW}{ }^{0.62}(6 \mathrm{~min})^{-1}\right]$. Subsequently, the $\%$ contribution of each macronutrient was derived and plotted against time of the day. A proportion of FOX $<0 \%$ of total EE indicates fat deposition.

In a further experimental subset, 33 piglets were allocated to the 4 experimental groups as described above to determine plasma NEFA concentrations at day 21 of FR (C and $\mathrm{R}$ pigs), day 7 ( $\mathrm{R}$ pigs only) and day 21 of RFD ( $\mathrm{C}$ and $\mathrm{R}$ pigs). To link diurnal FOX data with plasma NEFA concentrations, the plasma sampling times were expressed relative to the feeding times of the respiration experiment. Relative to the morning feeding blood samples were collected in Fluoride-EDTA coated tubes $(1.2 \mathrm{mg}$ EDTA $/ \mathrm{ml}$ blood; Monovette, Sarstedt, Nümbrecht, Germany) at -0.1, $1,2,3,4,5,6,7,8$ and $12 \mathrm{~h}$. Blood was put on ice and subsequently centrifuged $20 \mathrm{~min}$ at $1,573 \times g$ and $4{ }^{\circ} \mathrm{C}$ (Heraeus Multifuge 3 L-R, Kendro Laboratory Products, Osterode, Germany) to isolate the plasma, before storage at $-80{ }^{\circ} \mathrm{C}$ until analysis. Plasma NEFA concentrations were analyzed using kit no. 600-215S from Wako Chemicals GmbH (Neuss, Germany).

\section{Body composition}

Nine randomly selected pigs per group were slaughtered after an overnight fast at $131( \pm 1)$ d of age (after 30 days of RFD) by electro-stunning followed by exsanguination in the experimental abattoir of the Institute. Subsequently, liver, left and right kidney, pancreas and heart, as well as peritoneal and omental fat (both together termed abdominal fat) were removed and weighed. Twenty-four hours after slaughter several skeletal muscles ( $m$. longissimus dorsi, m. semitendinosus, and m. semimembranosus), backfat and subcutaneous fat covering neck, shoulder and ham were dissected from the left carcass half and weighed.

\section{Statistical analysis}

Data were analyzed by the MIXED procedure of SAS (version 9.3; SAS Inst. Inc., Cary, NC, USA). Post hoc comparisons were performed using the Tukey-Kramer test. Significance was considered at $P \leq 0.05$, and trends were discussed at $0.05<P \leq 0.1$. Results are reported as least square means (LSM) \pm SE. During model development, the original model included 'block' as a factor but because it had no significant influence as main effect or interaction it was excluded from the statistical model. To evaluate the variables COX, FOX and EE, and COX, FOX and $\mathrm{P}_{\text {dis }}$ as \% of $\mathrm{EE}, \mathrm{EB}, \mathrm{EE}_{\mathrm{PA}}, \mathrm{RQ}, Q$ value during ad libitum feeding, RMR and PA, the model included the fixed factors BiW class $(\mathrm{N}, \mathrm{L})$, feeding type $(\mathrm{C}, \mathrm{R})$, the repeated factor time point (T1, T2a, T2b, T3a, T3b) and interactions, and the sow as random factor. The latter allows us to model the dependency of the littermate piglets from the same sow. Food intake, food conversion ratio (FCR) and BW were analyzed separately at days 28, 79, 90, 101, 129/131, considering the fixed factors BiW class (N, L), feeding type $(\mathrm{C}, \mathrm{R})$ and interactions and the sow as random factor. The time course of plasma NEFA concentrations at day 21 of FR and on day 7 and day 21 of RFD was compared between groups at each time point separately using a model 

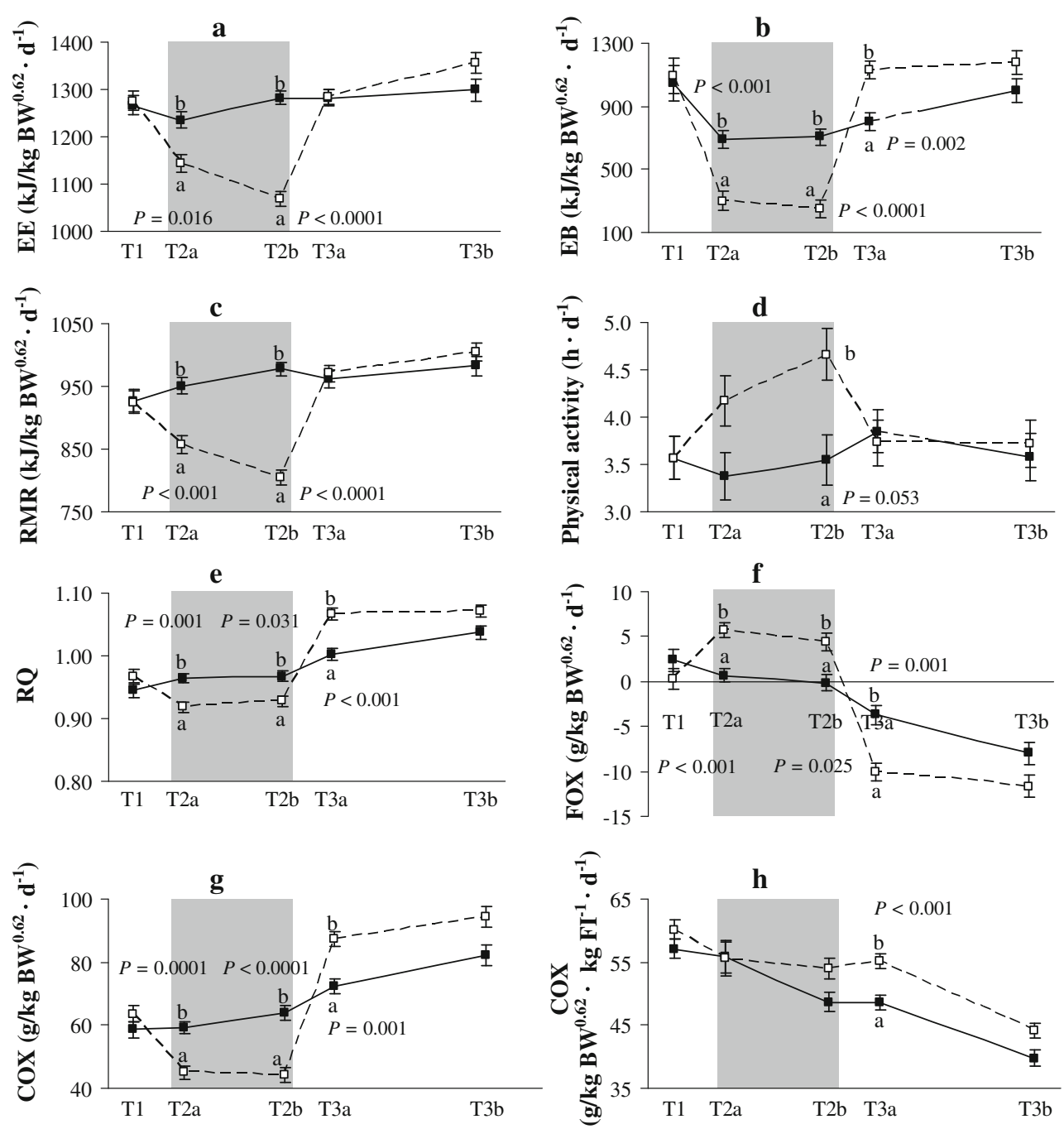

Fig. 1 Energy expenditure (EE) (a), energy balance (EB) (b), resting metabolic rate (RMR) (c), physical activity (d), RQ (e), fat oxidation (FOX) (f) and carbohydrate oxidation (COX) (g, h) before (T1), during (T2a and T2b) and after (T3a and T3b) food restriction (pooled

$\mathrm{LSM} \pm \mathrm{SE}$ ) for ad libitum fed pigs (solid line with filled square) and food restricted pigs (dashed line with open square ; $n=7-12$ /group). The food restriction period is shaded in gray. FI food intake

with the fixed factors BiW class (N, L), feeding type (C, R) and interactions with the sow as random factor.

\section{Results}

Food Intake, body weight and composition and food efficiency

Absolute food intake was lower in L pigs until age 79 days $(P<0.05$; Table 2). However, relative $\mathrm{FI} / \mathrm{kg} \mathrm{BW}$ was higher in $\mathrm{L}$ as compared to $\mathrm{N}$ pigs over the whole experimental period $(P<0.05$; Table 2; Online Resource 3$)$. Starch and sugar as well as fat intake $/ \mathrm{kg} \mathrm{BW}$ were affected by $\mathrm{BiW}(P<0.05)$, time point $(\mathrm{T} 1-\mathrm{T} 3)(P<0.001)$ and feeding type $(\mathrm{C}$ or $\mathrm{R}) \times$ time point interaction

$(P<0.001)$, whereas sugar intake was additionally affected by feeding type $(P<0.001)$. The latter is due to the fact that FR diet was devoid of added sugar (Table 1). Overall starch and sugar intake $/ \mathrm{kg} \mathrm{BW}$, as well as fat intake $/ \mathrm{kg}(1.80$ vs. $1.66 \mathrm{~g} / \mathrm{kg} \mathrm{BW})$ were generally higher in $\mathrm{L}$ pigs than in $\mathrm{N}$ pigs $(P<0.05)$. At T1, BW-related fat intake was about three times as high as compared to the remaining time points (T2a-T3b) due to the higher fat content in the diet until age 79 days (Table 1).

In L pigs, BW was permanently lower, compared to $\mathrm{N}$ pigs $(P<0.05$; Table 2, Online Resources 4 and 5). From birth to weaning, average BW gain in N pigs was $7.5 \mathrm{~kg}$ and in L pigs $5.8 \mathrm{~kg}(P<0.001)$. Also from weaning to the beginning of $\mathrm{FR}$, the $\mathrm{BW}$ gain in $\mathrm{N}$ and $\mathrm{L}$ pigs differed, with $\mathrm{N}$ pigs gaining $21 \mathrm{~kg}$ and $\mathrm{L}$ pigs $18 \mathrm{~kg}$, respectively $(P=0.004)$. In $\mathrm{R}$ pigs, relative starch and sugar intake were lower during the FR 
Table 2 Body weight (BW), food intake (FI), and food conversion ratio (FCR) in low (L) and normal (N) birth weight (BiW) pigs food restricted for 21 days (FR; age 80-100 day) and subsequently refed (RFD) ad libitum (R), and in pigs fed ad libitum throughout the experimental period $(\mathrm{C})$

\begin{tabular}{|c|c|c|c|c|c|c|}
\hline & \multicolumn{2}{|l|}{$\mathrm{N}$} & \multicolumn{2}{|l|}{$\mathrm{L}$} & \multicolumn{2}{|c|}{$P$ value $\mathrm{e}^{\mathrm{e}}$} \\
\hline & $\mathrm{C}$ & $\mathrm{R}$ & $\mathrm{C}$ & $\mathrm{R}$ & BiW & Feeding type \\
\hline \multicolumn{7}{|l|}{ BW $(\mathrm{kg})$ at age } \\
\hline 1 day; birth & $1.5^{\mathrm{b}} \pm 0.02$ & & $1.1^{\mathrm{a}} \pm 0.03$ & & $<0.001$ & \\
\hline 28 days; weaning & $9.0^{\mathrm{b}} \pm 0.26$ & & $6.9^{\mathrm{a}} \pm 0.27$ & & $<0.001$ & \\
\hline 79 days; prior to FR & $29.6^{\mathrm{b}} \pm 0.60$ & & $24.9^{\mathrm{a}} \pm 0.66$ & & $<0.001$ & \\
\hline 90 days; during FR & $36^{\mathrm{c}} \pm 1.0$ & $34^{\mathrm{bc}} \pm 1.0$ & $31^{\mathrm{ab}} \pm 1.1$ & $29^{\mathrm{a}} \pm 1.1$ & $<0.001$ & 0.070 \\
\hline 101 days; begin RFD & $43^{\mathrm{c}} \pm 1.1$ & $39^{\mathrm{bc}} \pm 1.1$ & $38^{\mathrm{ab}} \pm 1.2$ & $34^{\mathrm{a}} \pm 1.2$ & $<0.001$ & 0.003 \\
\hline 131 days; end of RFD ${ }^{f}$ & $71^{\mathrm{b}} \pm 1.8$ & $69^{\mathrm{ab}} \pm 1.8$ & $67^{\mathrm{ab}} \pm 2.0$ & $62^{\mathrm{a}} \pm 2.0$ & 0.012 & 0.061 \\
\hline \multicolumn{7}{|l|}{ Absolute FI $(\mathrm{g} / \mathrm{d})$ at age } \\
\hline 28 days; weaning & $306^{\mathrm{b}} \pm 9$ & & $270^{\mathrm{a}} \pm 9$ & & $<0.001$ & \\
\hline 79 days; prior to $\mathrm{FR}$ & $1307^{\mathrm{b}} \pm 55$ & & $1163^{\mathrm{a}} \pm 60$ & & 0.021 & \\
\hline 90 days; during FR & $1448^{\mathrm{b}} \pm 35$ & $825^{\mathrm{a}} \pm 35$ & $1397^{\mathrm{b}} \pm 38$ & $825^{\mathrm{a}} \pm 38$ & 0.486 & $<0.001$ \\
\hline 101 days; begin RFD & $1653 \pm 47$ & $1690 \pm 47$ & $1645 \pm 51$ & $1510 \pm 51$ & 0.056 & 0.321 \\
\hline 130 days; end of RFD & $2521 \pm 77$ & $2569 \pm 77$ & $2518 \pm 90$ & $2546 \pm 80$ & 0.870 & 0.644 \\
\hline \multicolumn{7}{|l|}{ FI related to $\mathrm{BW}(\mathrm{g} / \mathrm{kg} \mathrm{BW})$} \\
\hline 28 days; weaning & $34^{\mathrm{a}} \pm 2.0$ & & $41^{\mathrm{b}} \pm 2.2$ & & 0.006 & \\
\hline 79 days; before FR & $44 \pm 2.1$ & & $47 \pm 2.3$ & & 0.162 & \\
\hline 90 days; during FR & $40^{\mathrm{c}} \pm 1.0$ & $24^{\mathrm{a}} \pm 1.0$ & $45^{\mathrm{d}} \pm 1.1$ & $29^{\mathrm{b}} \pm 1.1$ & $<0.001$ & $<0.001$ \\
\hline 101 days; begin RFD & $39^{\mathrm{a}} \pm 1.0$ & $43^{\mathrm{b}} \pm 1.0$ & $43^{\mathrm{b}} \pm 1.1$ & $44^{\mathrm{b}} \pm 1.1$ & 0.032 & 0.012 \\
\hline 130 days; end of RFD & $37^{\mathrm{a}} \pm 1.2$ & $40^{\mathrm{ab}} \pm 1.2$ & $40^{\mathrm{ab}} \pm 1.4$ & $41^{\mathrm{b}} \pm 1.3$ & 0.038 & 0.043 \\
\hline \multicolumn{7}{|l|}{ FCR (kg FI/kg BW gain) } \\
\hline 28-79 days; prior to FR & $2.04 \pm 0.05$ & & $1.97 \pm 0.05$ & & 0.334 & \\
\hline 80-90 days; during early FR & $2.50^{\mathrm{b}} \pm 0.09$ & $2.23^{\mathrm{ab}} \pm 0.09$ & $2.12^{\mathrm{a}} \pm 0.10$ & $2.12^{\mathrm{a}} \pm 0.10$ & 0.008 & 0.162 \\
\hline 91-100 days; during late FR & $2.46^{\mathrm{b}} \pm 0.06$ & $1.67^{\mathrm{a}} \pm 0.06$ & $2.24^{\mathrm{b}} \pm 0.07$ & $1.67^{\mathrm{a}} \pm 0.07$ & 0.073 & $<0.001$ \\
\hline 101-130 days; during RFD & $2.43 \pm 0.07$ & $2.40 \pm 0.07$ & $2.31 \pm 0.08$ & $2.23 \pm 0.08$ & 0.075 & 0.459 \\
\hline
\end{tabular}

Values are $\mathrm{LSM} \pm \mathrm{SE}(n=9-12 /$ group$)$

a-d Within a row, LS means without a common superscript differ $(P \leq 0.05$, Tukey-Kramer test)

e A trend for BiW x Feeding type interaction was observed for FI/kg BW on day $101(P=0.078)$ and FCR between days 91 and 100 $(P=0.092) ; \mathrm{BiW} \times$ Feeding type interaction effects for all other variables were not significant $(P>0.1)$

${ }^{\mathrm{f}}$ Slaughter weight

period (13 vs. $21 \mathrm{~g} / \mathrm{kg} \mathrm{BW} P<0.001)$, but higher during early RFD (T3a; 23.5 vs. $19.9 \mathrm{~g} / \mathrm{kg}$ BW; $P<0.001$ ). Relative fat intake during FR was $\sim 60 \%$ of ad libitum fed $\mathrm{C}$ pigs $(P<0.001)$ as targeted, with no difference between $\mathrm{L}$ and $\mathrm{N}$ pigs $(P>0.6)$. In previously food restricted $\mathrm{N}$ pigs, relative fat intake was higher during early RFD (T3a) (1.5 vs. $1.2 \mathrm{~g} / \mathrm{kg}$ BW; $P<0.05)$. The 3 -week FR delayed BW gain by about $30 \%$ as compared to age-matched C pigs (R pigs $9.5 \mathrm{~kg}$; C pigs $13.6 \mathrm{~kg} ; P<0.001)$, with no differences regarding the BiW class (Table 2). After 30 days of RFD, BW tended to be still decreased in previously food restricted pigs $(P=0.06)$, although $\mathrm{FI} / \mathrm{kg} \mathrm{BW}$ was permanently higher during RFD $(P<0.04$; Online Resource 3).

A low BiW improved or tended to improve FCR during FR and RFD (Table 2; Online Resource 5). Furthermore, pigs during late FR showed a better FCR as well $(P<0.001)$.
Irrespective of $\mathrm{BiW}$ and in agreement to FCR data, the $Q$ value as another indicator for food utilization was lower in R compared to $\mathrm{C}$ pigs at the age of 104 days (Table 3; T3a; $P<0.001)$. This indicates lower heat loss in R pigs during early RFD favoring energy deposition during that period. Averaged over the total of 30 days RFD period, however, FCR of previously food restricted pigs did not differ from agematched controls (Table 2). Irrespective of the FR and RFD periods, at age day $131, \mathrm{~L}$ pigs showed decreased weights of $m$. semimembranosus and $m$. semitendinosus $(P<0.05)$, higher percentage of abdominal fat (1.7 vs. $1.45 \% \mathrm{BW}$; $P=0.002)$ and a trend toward an increased carcass fat proportion (5.4 vs. $5.0 \%$ of half carcass; $P=0.06$ ) (Table 4 ). Food restriction resulted in persistently lower weights of abdominal fat depots after 30 days of RFD independent of the pigs' $\operatorname{BiW}(P=0.015)$. 


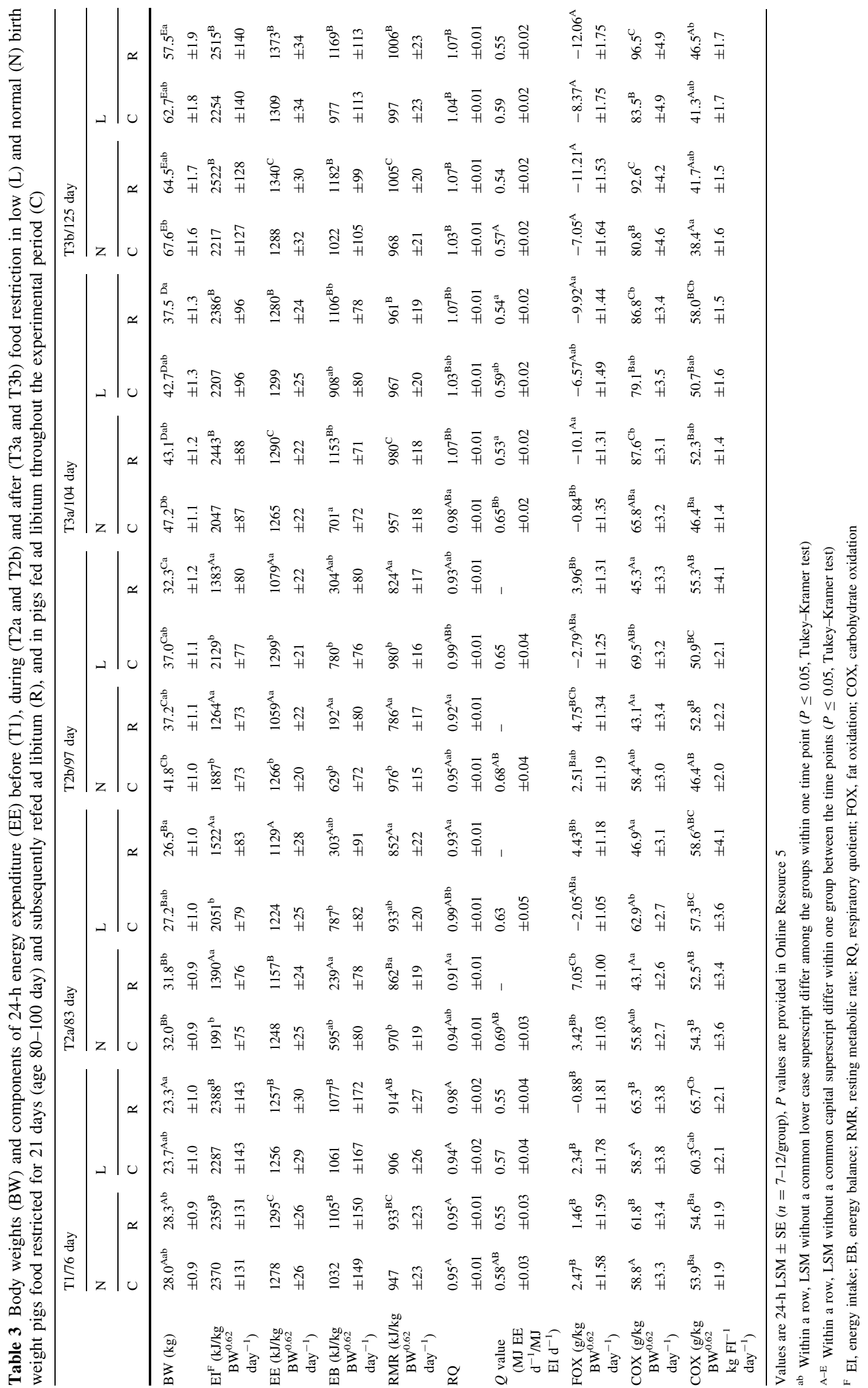


24-h energy metabolism

\section{Effects of birth weight and age}

Birth weight did not affect EE, EB and RMR (all $P>0.3$; Table 3; Online Resource 5). However, PA was lower in L pigs at T1 (3.0 vs. $4.1 \mathrm{~h} /$ day) and T2a ( 3.3 vs. $4.4 \mathrm{~h} /$ day) $(P=0.040)$, but $\mathrm{EE}_{\mathrm{PA}}$ was not affected by BiW $(P>0.4)$.

With increasing age, the contribution of FOX to EE steadily decreased in ad libitum fed pigs with normal BiW (Table 3; FOX became negative). However, FOX was affected by $\mathrm{BiW}(P=0.006$; Online Resource 5$)$. At age 83 days (T2a), but not at 76 days (T1), FOX was lower in $\mathrm{L}$ compared to $\mathrm{N}$ pigs $(P=0.007)$, in spite of similar fat intake in the two groups. In LC pigs, FOX was already negative at the age of 83 days (T2a), whereas in NC pigs, FOX became negative later, on day 104 (T3a; Table 3). Irrespective of age and feeding level, overall, L pigs generally exhibited a lower FOX (i.e., greater fat deposition) throughout the experimental period compared to $\mathrm{N}$ pigs ( $\mathrm{N}$ vs. $\mathrm{L}:-0.8$ vs. $-3.2 \mathrm{~g} / \mathrm{kg}$ $\left.\mathrm{BW}^{0.62} ; P=0.006\right)$. In line with this, $\mathrm{L}$ pigs showed a higher RQ value ( $\mathrm{N}$ vs. L: 0.98 vs. $1.00 ; P=0.006$; Table 3). In contrast, a low BiW was associated with a higher COX, compared to N pigs (N vs. L: 65 vs. $69 \mathrm{~g} /$ $\mathrm{kg} \mathrm{BW}^{0.62} ; P=0.026$; Table 3).

\section{Effects of food restriction and refeeding}

Energy expenditure and RMR decreased in response to FR in $\mathrm{R}$ pigs as compared to age-matched $\mathrm{C}$ pigs with ad libitum feeding (Fig. 1; T2a and T2b: both $P<0.001$ ), also resulting in a less positive EB irrespective of the pigs' BiW (Table 3). Resting metabolic rate was significantly reduced only after 17 days of FR (T2b), and at the same time, $\mathrm{PA}$ in $\mathrm{R}$ pigs was higher compared to $\mathrm{C}$ pigs $(P=0.024)$. However, $\mathrm{EE}_{\mathrm{PA}}$ was similar between $\mathrm{R}$ and $\mathrm{C}$ pigs $(P=0.514)$. Food restriction increased FOX when related to BW and expressed as a percentage of total $\mathrm{EE}$ $(P=0.008)$, which was irrespective of BiW (Table 3; Online Resource 5). During FR COX related to BW and as a percentage of total EE decreased (Fig. 1; T2a and T2b). Four d after the start of RFD (day 104; T3a), EI tended to be higher in $\mathrm{R}$ than in $\mathrm{C}$ pigs $(P=0.07)$, resulting in a more positive $\mathrm{EB}$ as compared to $\mathrm{C}$ pigs $(P=0.002$; Table 3; Fig. 1). The more positive EB only after 4 days of RFD (T3a) in $\mathrm{R}$ pigs was associated with a distinctly decreased FOX which went below the level found in $\mathrm{C}$ pigs (Table 3). In addition, at 4 days of RFD (T3a), COX adjusted for BW and FI was higher in R than in $\mathrm{C}$ pigs (C vs. R, 48.6 vs. $\left.55.2 \mathrm{~g} / \mathrm{kg} \mathrm{BW}^{0.62} \mathrm{FI}^{-1} ; P<0.001\right)$, irrespective of BiW (Fig. 1).
Substrate oxidation pattern during $24 \mathrm{~h}$ and plasma NEFA concentrations

Although substrate oxidation pattern (COX and FOX in \% of total EE) varied in response to age (both $P<0.0001$ ) and feeding type (at T2a to T3a: COX, $P<0.005$; FOX, $P<0.008)$, carbohydrates were the primary energy source (>78\% of EE; Figs. 2 and 3 ) and their contribution to total EE was higher in $\mathrm{L}$ than in $\mathrm{N}$ pigs $(P=0.005)$. In contrast, in $\mathrm{L}$ pigs FOX \% was lower $(P=0.006)$.

Independent of age, the intake of the morning meal after an overnight fast caused a sharp decrease in FOX, followed by a transiently neutral fat balance for $1.5-2 \mathrm{~h}$ in NC pigs (Fig. 3). Simultaneously, and in parallel with the course of FOX, plasma NEFA concentrations dropped within $1 \mathrm{~h}$ after provision of food and remained at a low level over the next $12 \mathrm{~h}$. In $\mathrm{N}$ pigs, FR (T2a and T2b) considerably increased FOX suggesting fat synthesis to not occur during the day. After the afternoon meal, FOX declined and increased again $6 \mathrm{~h}$ later to continue until the next morning (Figs. 2 and 3). In R pigs, the plasma NEFA concentrations started to re-increase 4-5 $\mathrm{h}$ after the intake of the morning meal and were higher than in $\mathrm{C}$ pigs $(P<0.001$; Figs. 2 and 3; Online Resource 6). Additionally, in R pigs, plasma NEFA concentrations were higher prior to the morning meal than prior to the afternoon meal (402 and $248 \mu \mathrm{mol} /$ $\mathrm{L}, P<0.001)$, respectively, which is due to the longer time without food between afternoon and morning meal (18 h). In contrast, in C pigs, plasma NEFA concentrations from $2 \mathrm{~h}$ after the meal onwards remained at the same low level (47-70 $\mu \mathrm{mol} / \mathrm{L}$; Figs. 2 and 3; Online Resource 6). In LR pigs, after 4 days of FR (T2a), $1.5 \mathrm{~h}$ after the afternoon meal fat balance became neutral before FOX re-increased $9 \mathrm{~h}$ after the meal (Fig. 3). In contrast, in age-matched NR (T2a) pigs, FOX increased already $6 \mathrm{~h}$ after the afternoon meal. However, 24-h FOX was not different (LR vs. NR, T2a, $P=0.96$; Figs. 2 and 3 ).

Between day 104 (T3a) and day 125 (T3b) of age, the $\mathrm{NC}$ pigs rapidly entered a phase of elevated endogenous fat synthesis (i.e., negative FOX) after the morning meal. This was enhanced by the consumption of the afternoon meal and lasted 9-12 $\mathrm{h}$ after that, even after withdrawal of food $(1800 \mathrm{~h}$ ). At the younger ages (T1 to T2b), the switch from fat synthesis to FOX during the night occurred earlier than at the later stages. Higher fat synthesis (i.e., negative FOX) was balanced by increased COX. In general, plasma NEFA values did not differ between $\mathrm{N}$ and $\mathrm{L}$ pigs $(P>0.1)$. However, in ad libitum fed $\mathrm{N}$ and L pigs plasma NEFA levels prior to the morning meal increased with age and were nearly twice as high at 125 days (T3b) than those observed 3 weeks earlier (T2b) (Online Resource 6). After 4 days of RFD (T3a) in R pigs, FOX only briefly occurred 
Table 4 Weights of organs, fat depots and skeletal muscles at the age of 131 days in low (L) and normal (N) birth weight (BiW) pigs food restricted for 21 days (age 80-100 day) and subsequently refed ad libitum (R), and in pigs fed ad libitum throughout the experimental period (C)

\begin{tabular}{|c|c|c|c|c|c|c|}
\hline & \multicolumn{2}{|l|}{$\mathrm{N}$} & \multicolumn{2}{|l|}{$\mathrm{L}$} & \multicolumn{2}{|c|}{$P$ value $^{\mathrm{c}}$} \\
\hline & $\mathrm{C}$ & $\mathrm{R}$ & $\mathrm{C}$ & $\mathrm{R}$ & $\mathrm{BiW}$ & Feeding type \\
\hline \multicolumn{7}{|l|}{ Fat depots } \\
\hline Omental fat & $508^{\mathrm{ab}} \pm 28$ & $450^{\mathrm{a}} \pm 28$ & $567^{\mathrm{b}} \pm 30$ & $495^{\mathrm{ab}} \pm 28$ & 0.077 & 0.044 \\
\hline Ventral visceral fat & $550^{\mathrm{ab}} \pm 48$ & $493^{\mathrm{ab}} \pm 48$ & $671^{\mathrm{b}} \pm 52$ & $453^{\mathrm{a}} \pm 48$ & 0.432 & 0.016 \\
\hline$\Sigma$ Abdominal fat & $1058^{\mathrm{ab}} \pm 66$ & $943^{\mathrm{a}} \pm 66$ & $1237^{\mathrm{b}} \pm 71$ & $970^{\mathrm{ab}} \pm 66$ & 0.150 & 0.015 \\
\hline \multicolumn{7}{|c|}{ Subcutaneous fat ${ }^{\mathrm{d}}$ covering } \\
\hline Shoulder & $400 \pm 37$ & $445 \pm 37$ & $393 \pm 39$ & $360 \pm 37$ & 0.171 & 0.893 \\
\hline Neck & $335 \pm 32$ & $326 \pm 32$ & $373 \pm 34$ & $350 \pm 32$ & 0.631 & 0.162 \\
\hline Ham & $890 \pm 64$ & $868 \pm 64$ & $960 \pm 69$ & $749 \pm 64$ & 0.712 & 0.104 \\
\hline Backfat $^{\mathrm{d}}$ & $843 \pm 87$ & $755 \pm 87$ & $874 \pm 94$ & $676 \pm 87$ & 0.789 & 0.137 \\
\hline$\Sigma$ Fat depots ${ }^{\mathrm{e}}$ & $3527 \pm 227$ & $3337 \pm 227$ & $3833 \pm 244$ & $3083 \pm 227$ & 0.912 & 0.065 \\
\hline \multicolumn{7}{|l|}{ Organs } \\
\hline Liver & $1240 \pm 50$ & $1295 \pm 50$ & $1284 \pm 53$ & $1241 \pm 50$ & 0.911 & 0.909 \\
\hline Kidneys (mean) & $132 \pm 5$ & $134 \pm 5$ & $131 \pm 5$ & $129 \pm 5$ & 0.471 & 0.993 \\
\hline Heart & $283 \pm 11$ & $274 \pm 11$ & $270 \pm 12$ & $254 \pm 11$ & 0.178 & 0.311 \\
\hline Pancreas & $121 \pm 7$ & $117 \pm 7$ & $118 \pm 7$ & $109 \pm 7$ & 0.450 & 0.348 \\
\hline \multicolumn{7}{|l|}{ Muscles $^{\mathrm{d}}$} \\
\hline M. longissimus dorsi & $1677 \pm 89$ & $1727 \pm 89$ & $1670 \pm 95$ & $1493 \pm 89$ & 0.203 & 0.494 \\
\hline M. semimembranosus & $1038 \pm 42$ & $1011 \pm 42$ & $947 \pm 45$ & $875 \pm 42$ & 0.020 & 0.275 \\
\hline M. semitendinosus & $332^{\mathrm{b}} \pm 13$ & $298^{\mathrm{ab}} \pm 13$ & $303^{\mathrm{ab}} \pm 14$ & $262^{\mathrm{a}} \pm 13$ & 0.035 & 0.018 \\
\hline
\end{tabular}

Values are $\mathrm{LSM} \pm \mathrm{SE}(n=8-9 /$ group $)$; all weights are in $\mathrm{g}$

ab Within a row, LSM without a common superscript differ $(P \leq 0.05$, Tukey-Kramer test $)$

c $\mathrm{BiW} \times$ Feeding type interaction effects for all variables were not significant $(P>0.1)$

d Tissue weights are related to the left half carcass

e Sum of the weights of abdominal fat depots, subcutaneous fat covering shoulder, neck and ham, and backfat

previous to the morning meal (1 h; Figs. 2 and 3). As reflected by a RQ value of 1.07 after 4 days of RFD (T3a), 24-h fat synthesis overcompensated in R pigs as compared to age-matched $\mathrm{C}$ pigs (Table 3). At day 125 (T3b), the substrate oxidation pattern was similar in all groups.

\section{Discussion}

\section{Effects of birth weight}

In spite of the higher BW-related FI in L pigs throughout the experimental period (with exception of day 79), BW and BW gain were lower in L pigs. Also, selected muscle weights were lower, but body fatness was still higher even after FR and RFD. Others also have found that IUGR was associated with impaired postnatal growth, lower lean mass, a higher fat percentage and intramuscular fat, enlarged, but lower numbers of muscle fibers, as well as a higher proportion of connective tissue [10, 11, 28-31]. It might be speculated that the lower muscle mass of IUGR pigs is in part responsible for their higher body fatness because it translates into less energy-consuming metabolically active tissue. As a result, more energy might be available to be deposited as fat [10, 32]. Similar observations have been made in human subjects previously small for gestational age at birth, and formerly malnourished children and adults where the body fat content was higher than in well-nourished individuals at the same age [32]. This was termed the 'catch-up fat phenomenon,' whereas the rebuilding of muscles was delayed [32]. It has been reported previously that the development of the gastrointestinal tract of IUGR pigs and the maturation of the digestive function postweaning were delayed $[13,33,34]$. This is thought to contribute to a reduced efficiency of nutrient utilization during growth [8]. However, in the present study, a low BiW improved or tended to improve FCR during FR and RFD. Other reports are contradictory in regard to increased energetic efficiency during FR as compared to ad libitum feeding in juvenile pigs [15, 35]. An increased food or energetic efficiency might suggest that FR and IUGR have induced a thrifty metabolism. During FR, this was also reflected by a reduced basal metabolic rate and a positive $\mathrm{EB}$, which still allowed some BW gain. 

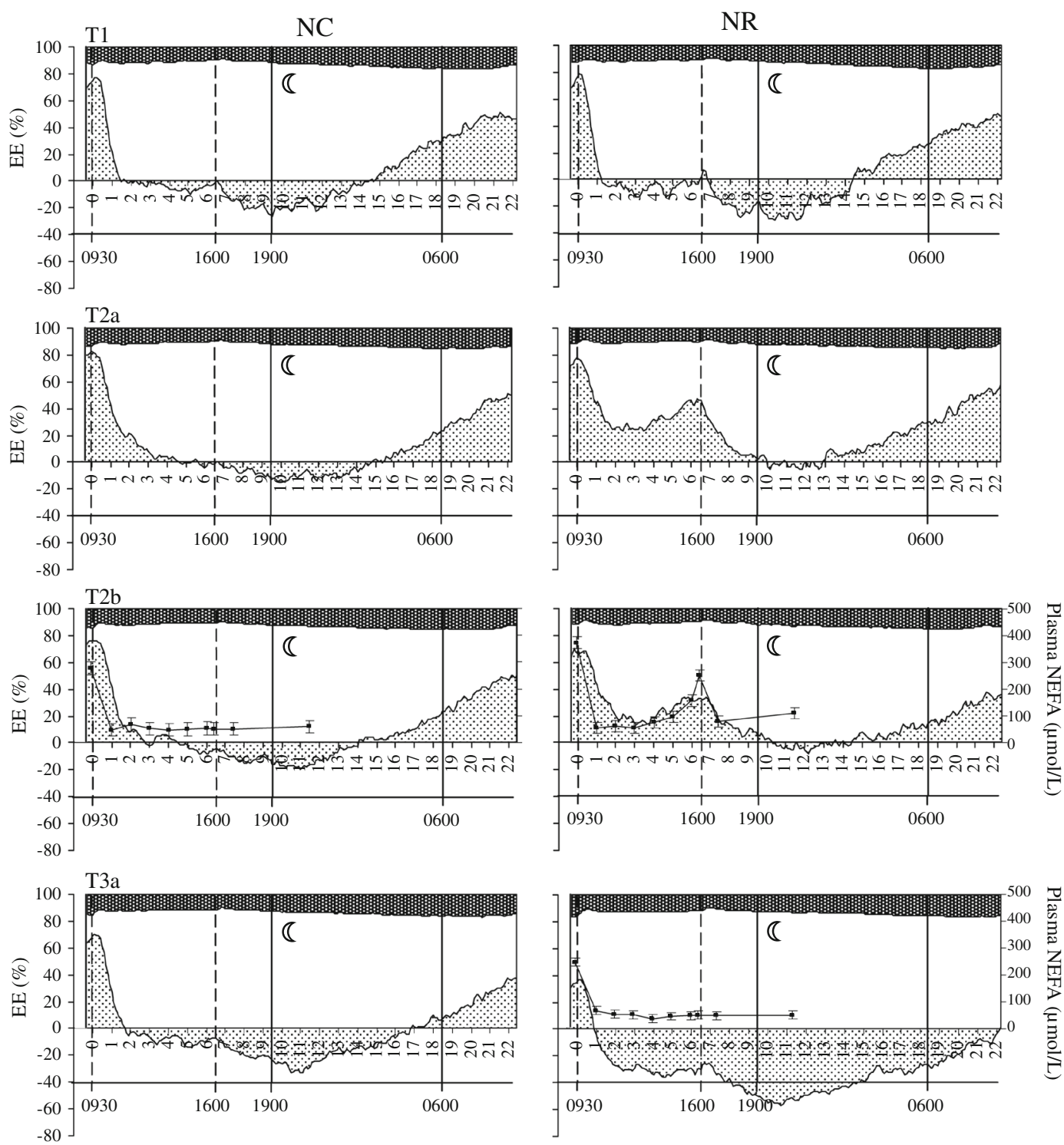

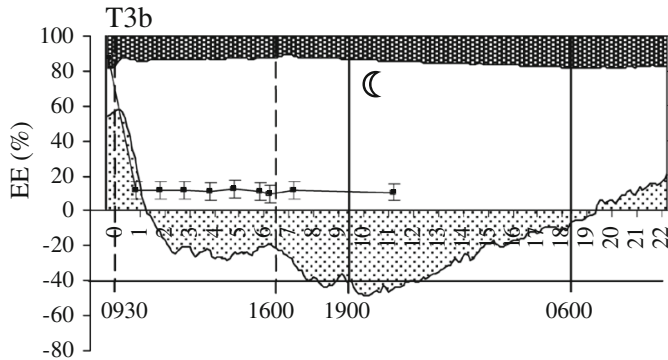

Time relative to morning feeding

(h) and real time

Fig. 2 Diurnal patterns of fat, carbohydrate and protein disappearance (from bottom to top: fat oxidation, gray shading; carbohydrate oxidation, blank area; protein disappearance, dark shading) expressed as $\%$ of total energy expenditure (EE; left y-axis; LSM; SE were omitted for the sake of clarity) and related to plasma NEFA concentration (right y-axis, solid line with filled square; $\mathrm{LSM} \pm \mathrm{SE}$ ) in ad libitum fed pigs with normal birth weight (NC; left panels;

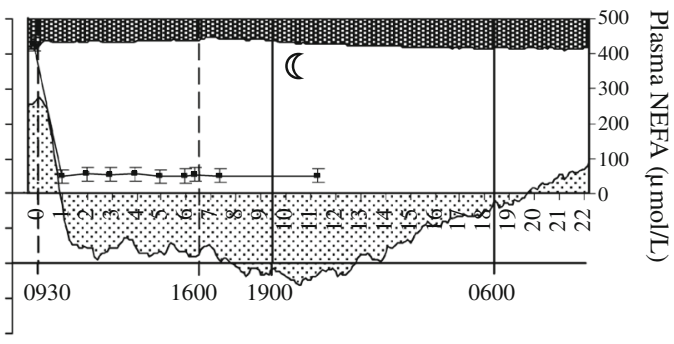

Time relative to morning feeding

(h) and real time

$n=6-7 /$ group) and food restricted pigs with normal birth weight (NR; right panels; $n=9$ /group) before (top panel: T1), during (middle panels: $\mathrm{T} 2 \mathrm{a}$ and $\mathrm{T} 2 \mathrm{~b}$ ) and after (bottom panels: $\mathrm{T} 3 \mathrm{a}$ and $\mathrm{T} 3 \mathrm{~b}$ ) food restriction. Vertical dashed lines indicate the feeding time points within day. The time period between 1900 and $0600 \mathrm{~h}$ marked with a half-moon represents the night phase. Negative fat oxidation values indicate fat synthesis 

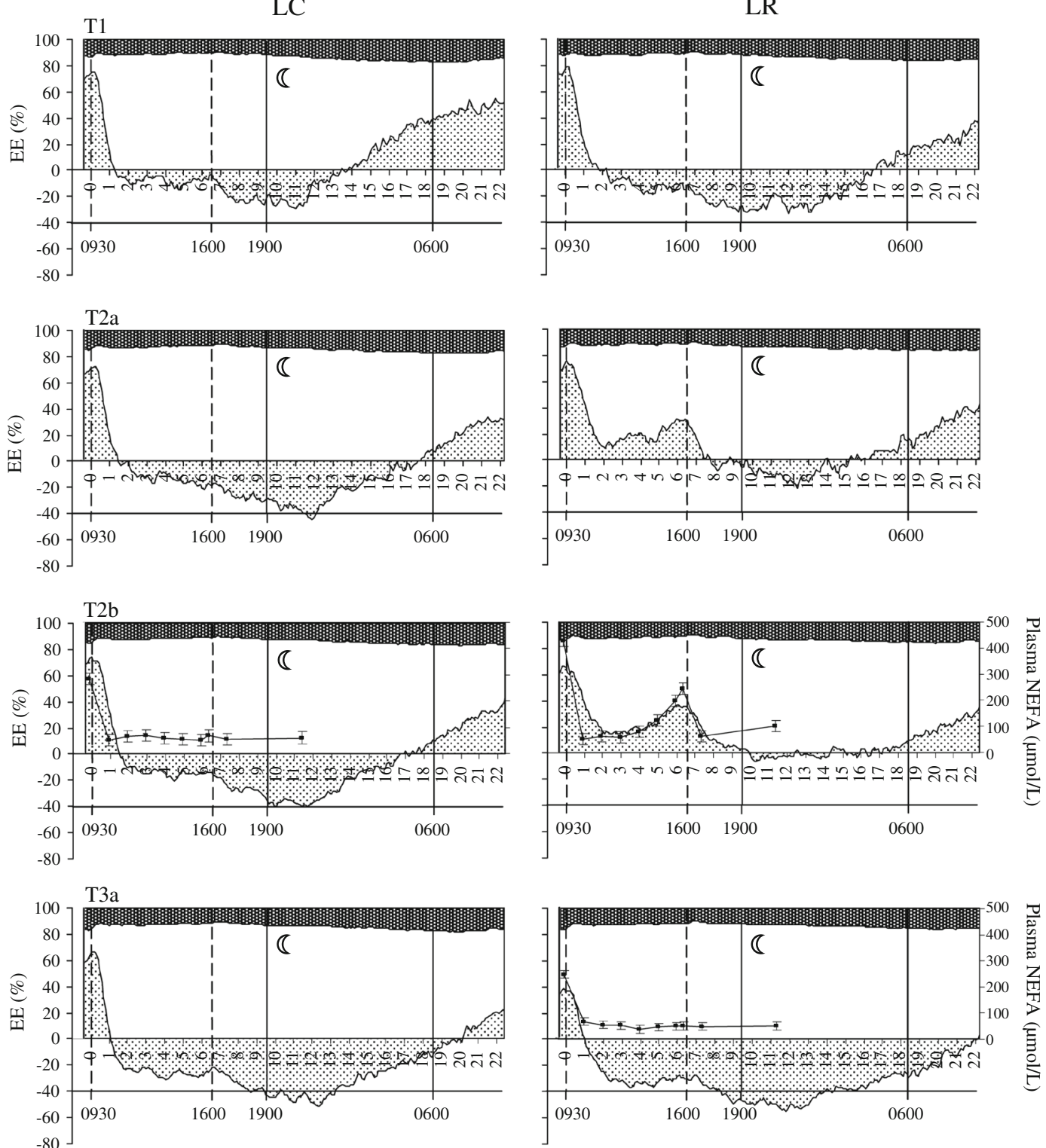

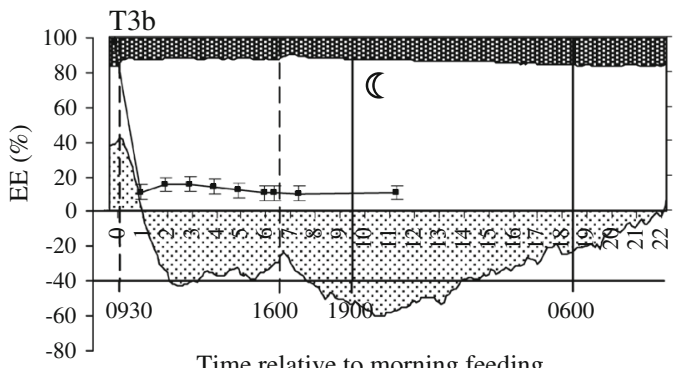

Time relative to morning feeding (h) and real time

Fig. 3 Diurnal patterns of fat, carbohydrate and protein disappearance (from bottom to top: fat oxidation, gray shading; carbohydrate oxidation, blank area; protein disappearance, dark shading) expressed as \% of total energy expenditure (EE; left y-axis; LSM; SE were omitted for the sake of clarity) and related to plasma NEFA concentration (right y-axis, solid line with filled square; $\mathrm{LSM} \pm \mathrm{SE}$ ) in ad libitum fed pigs with low birth weight (LC; left panels; $n=8$ /

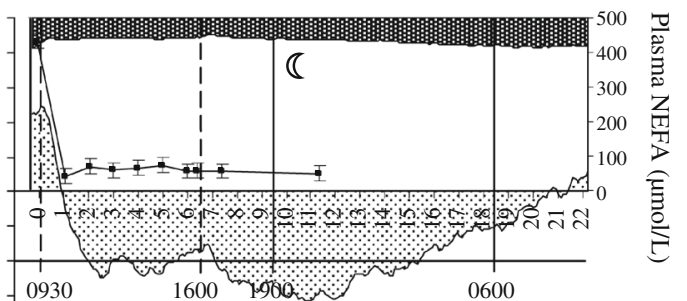

Time relative to morning feeding

(h) and real time

group) and food restricted pigs with low birth weight (LR; right panels; $\mathrm{n}=8-9 /$ group) before (top panel: $\mathrm{T} 1$ ), during (middle panels: $\mathrm{T} 2 \mathrm{a}$ and $\mathrm{T} 2 \mathrm{~b}$ ) and after (bottom panels: T3a and T3b) food restriction. Vertical dashed lines indicate the feeding time points within day. The time period between 1900 and $0600 \mathrm{~h}$ marked with a half-moon represents the night phase. Negative fat oxidation values indicate fat synthesis 
In contrast to our hypothesis, we could not find differences in EE and basal metabolic rate between L (IUGR) and $\mathrm{N}$ pigs. However, PA was lower in L pigs at $\mathrm{T} 1$ and T2a, which might have contributed to greater fat deposition. Our data suggest that in ad libitum fed L pigs fat deposition begins at an earlier age than in $\mathrm{N}$ pigs which did not show a negative FOX until 20 days later on day 104. Irrespective of age and feeding level, L pigs generally exhibited a lower FOX (i.e., greater fat deposition) throughout the experimental period, although their relative fat intake was $\sim 10 \%$ higher, which should have rather stimulated FOX [36]. A higher RQ value in L pigs confirms higher fat synthesis. Lower FOX contrasted with a higher COX which might be a consequence of the $\sim 10 \%$ higher relative food and carbohydrate intake in $\mathrm{L}$ pigs and related to the higher propensity for fat deposition, as glucose is used as a precursor for fatty acid synthesis and to supply NADPH for fatty acid synthesis. Thus, the difference in fuel selection of $\mathrm{L}$ pigs as compared to $\mathrm{N}$ pigs underlies the propensity for greater fat deposition in IUGR individuals as observed in this study as well as by others [10, 37, 38].

\section{Effects of food restriction and refeeding}

Temporary FR, dieting or starvation, is associated with decreased EE and basal metabolic rate, as well as increased FOX and decreased COX [14-16, 39] which was confirmed by the present data. That the feeding level affects maintenance requirements has been recently reported in growing pigs [40]. The decrease in BW-adjusted RMR and EE is considered a mechanisms to survive deficient energy supply and to oppose FR-induced BW loss [41, 42]. Koong et al. [43, 44] showed in pigs that the fasting heat production was highly correlated with the mass of metabolically active organs and suggested that the mass of viscera is critical in the determination of RMR. In rats and humans gut and liver contribute 30-40\% to resting EE [42]. That RMR was significantly reduced only after 17 days of FR, indicates that it required $\sim 2$ week to adjust the visceral organs to the new feeding level. Similar to food restricted mice [45], PA in R pigs was higher compared to $\mathrm{C}$ pigs during FR, possibly due to food searching behavior. In line with another study [15], however, $\mathrm{EE}_{\mathrm{PA}}$ was unrelated to FR probably resulting from proportional similar changes of RMR and EE (Table 3). The $\mathrm{EE}_{\mathrm{PA}}$ amounted to $14 \%$ of total EE which is similar to values reported earlier in pigs $(8-18 \%)[15,46]$.

Decreased EE during FR and a re-increase due to RFD were found earlier in pigs [15]. In adult human weight regainers, a reduced resting $\mathrm{EE}$ after 6 months of realimentation was observed [47]. In contrast, 30 days of RFD was not long enough to have our R pigs return to the $\mathrm{BW}$ of their ad libitum fed age-matched controls. Similarly, in growing pigs (BW $52 \mathrm{~kg}$ ), 7 days of FR (60\% of ad libitum FI) followed by 1 week of RFD resulted in reduced BW gain and lower BW (71 vs. $74 \mathrm{~kg}$ ) [15]. Seventy daysold pigs fed restrictively for 28 to 60 days (until age 98 or 130 days) and subsequently refed ad libitum until the age of 140 days, did also not compensate the BW difference to ad libitum fed pigs [29]. In contrast, 62 days of $60 \%$ of ad libitum FI in pigs starting at weaning (day 28) and subsequent RFD did not result in BW differences at the age of 145 days compared to the respective controls [30]. Thus, the extent of BW reduction after FR and ad libitum RFD is a function of age (i.e., growth rate), degree and duration of FR and RFD.

The intake of fat in $\mathrm{R}$ pigs during FR was $26.4 \mathrm{~g} / \mathrm{d}$ (825 $\mathrm{g}$ food/d with $3.2 \%$ crude fat). In early FR (T2a), we found that in NR pigs $\sim 60 \mathrm{~g}$ fat/d was oxidized. This suggests that in NR pigs, more than $50 \%$ of total FOX must be accounted for by fat depot mobilization and/or an increase in endogenous fat synthesis. We found higher plasma NEFA concentrations in $\mathrm{R}$ pigs pointing to an increased fat depot mobilization (Figs. 2 and 3; Online Resource 6). That FR is associated with endogenous fat synthesis was found in another indirect calorimetry study which was supported by tracer data showing endogenous fatty acid synthesis in food restricted mice $(70 \%$ of ad libitum intake) [16]. In contrast, in ad libitum fed NC pigs, the dietary fat intake at T2a was $54 \mathrm{~g} /$ day and the measured FOX amounted to $26 \mathrm{~g} /$ day suggesting that $>50 \%$ of the consumed fat is deposited in the body. The oxidized amount of fat in LR pigs ( $\sim 30 \mathrm{~g}$ fat/day) was similar to what was ingested with the food and suggests that fat balance in L pigs was neutral during the FR period. In contrast, the fat balance of the age-matched LC pigs was +35 g/day (fat intake $53 \mathrm{~g} / \mathrm{d}$; FOX $17.7 \mathrm{~g} /$ day). Thus, NR and LR pigs oxidized 2.3 and 1.7 times as much fat, respectively, than their age-matched, ad libitum fed counterparts. In addition, in LR pigs, FOX was only $\sim 50 \%$ of what was oxidized in NR pigs during the early FR period. This pointed to less fat mobilization in L pigs during FR. During the same period, COX (\% of EE) was higher in $\mathrm{L}$ compared to $\mathrm{N}$ pigs, suggesting a higher glucose utilization to supply NADPH for fatty acid synthesis and as a precursor for fat synthesis [16, 48, 49].

The positive EB during early RFD was accompanied by a distinctly decreased FOX leading presumably to a replenishment of the depleted fat depots. This is in line with a suppressed fat oxidation early during RFD of rats after BW loss [50]. In contrast, COX adjusted for BW and $\mathrm{FI}$ was higher in $\mathrm{R}$ than in $\mathrm{C}$ pigs, irrespective of $\mathrm{BiW}$. This might reflect an enhanced utilization of glucose for fat synthesis [16, 48, 49]. A low ratio of FOX/COX was reported to be a risk factor for weight regain in post-dieting human subjects which is similar to our observations in $\mathrm{R}$ 
pigs during early RFD [50]. Possibly, this might be additionally fuelled by an increased intestinal absorptive capacity for carbohydrates as a means of adaptation to FR as shown previously in mice [51, 52].

Food restriction resulted in persistently lower absolute and relative weights of abdominal fat depots after 30 days of RFD independent of the pigs' BiW. This can be explained by increased lipolysis as indicated by the higher plasma NEFA concentrations and FOX. During the RFD period of 30 days, fat depots were supposedly replenished, but the FR-induced decrease in abdominal fat depot weight still persisted. Whether a previous FR period is still reflected in reduced body fat later on depends on the duration of time and severity of FR, as well as the duration of and energy intake during RFD as shown previously in pigs [30]. Thus, referring to our outgoing hypothesis, the RFD period following the FR period was not long enough to know whether FR leads to a faster rate of fat recovery relative to lean tissue recovery in the longer term.

Substrate oxidation pattern during $24 \mathrm{~h}$ and plasma NEFA concentrations

That in pigs carbohydrates are the major fuel is in line with earlier findings in adequately nourished growing pigs (40-100 kg) where COX provided $85 \%$ of EE, followed by protein oxidation (15\%) with no contribution of FOX to EE in these pigs [53]. This is related to the fact that the typical pig diet is high in carbohydrates and low in fat and thus leads to fat synthesis rather than to FOX [54]. In growing pigs, fat is oxidized if energy supply is insufficient for growth, even if dietary fat content is moderately high [53]. However, in NC pigs with $<40 \mathrm{~kg} \mathrm{BW}$, we found a small contribution of FOX (8-10\% of total EE), while COX contribution was $80 \%$. Others reported contributions of $30 \% \mathrm{FOX}$ and $55 \% \mathrm{COX}$ to total EE in even lighter pigs (30 kg BW) [55]. This confirms that the nutrient oxidation pattern shifts with age in growing pigs toward an increasingly smaller contribution of FOX, and in turn, a higher fat deposition $[55,56]$.

In food restricted mice (70\% of ad libitum intake), consuming their food in one single meal, FOX did not occur for the next $7 \mathrm{~h}$ before it increased and remained at a plateau until the next morning [16]. Compared to the latter study, in our R pigs, the morning FI was insufficient to completely suppress FOX. This is due to the relatively lower amount of dietary energy supplied during the morning meal in our study, leaving the pigs in an energy deficient state. This interpretation is in line with the course of the plasma NEFA concentrations which started to reincrease $4-5 \mathrm{~h}$ after the intake of the morning meal and were higher than in C pigs. After 4 days of FR (T2a) in LR pigs, fat balance was neutral between 1.5 and $9 \mathrm{~h}$ after the afternoon meal, before FOX re-increased. In contrast, in age-matched NR (T2a) pigs, FOX increased already $6 \mathrm{~h}$ after the afternoon meal. This suggests a different diurnal substrate oxidation pattern between L pigs (IUGR) and normal BiW pigs during FR.

\section{Conclusion}

We confirmed that IUGR pigs have a lower capacity for growth and muscle development. Based on our outgoing hypotheses, we observed no differences in EE and RMR between IUGR pigs and their age-matched controls in spite of a higher BW-related FI in IUGR pigs. However, IUGR pigs oxidized less fat than $\mathrm{N}$ pigs which underlies their higher body fatness and results in an enhanced fat deposition at an earlier age. During a 3-weeks period of FR, BW gain was delayed, body fat was mobilized and FOX was higher than in ad libitum fed pigs. Food restricted $\mathrm{N}$ and $\mathrm{L}$ pigs oxidized about 2 times as much fat as their ad libitum fed counterparts. During FR, in LR pigs, FOX was only $50 \%$ of that in NR pigs suggesting a fairly neutral fat balance during FR in IUGR pigs. IUGR pigs showed a different diurnal substrate oxidation pattern than normal BiW pigs during FR. During the first few d of RFD, FI was higher leading to a more positive EB and a more intense stimulation of fat synthesis. This was not different between IUGR and normal BiW pigs. After 30 days of RFD, no differences in components of EE among the four groups remained, but low BiW and FR resulted in higher and lower body fatness of pigs, respectively. Taken together, higher body fat in IUGR pigs, especially abdominal fat, is likely due to a lower potential for muscle accretion, an earlier onset of fat deposition due to a lower ratio of FOX to COX, and a different diurnal fuel selection during FR.

Acknowledgments Financial support was provided by the German Federal Ministry of Education and Research (BMBF) in the framework of 'Biomedizinische Ernährungsforschung' (Vision Epifood, FKZ 0315397B). The authors take responsibility for the content of the work. The authors express their gratitude to K. Grot and C. Arlt (Leibniz Institute for Farm Animal Biology; Institute of Nutritional Physiology) for excellent laboratory assistance. Furthermore, the authors gratefully acknowledge Dr. B. Stabenow and his team, Dr. O. Bellmann, T. Lenke, R. Gaeth, D. Oswald, A. Schulz and K. Pilz (all Leibniz Institute for Farm Animal Biology) as well as M. Marionvalle (l'Ecole d'Ingénieurs de Purpan, France) and A. Myers (University of Maryland, USA) for animal care, medical supervision and assistance with respiration measurements, respectively.

Conflict of interest The authors declare that they have no conflict of interest.

Open Access This article is distributed under the terms of the Creative Commons Attribution License which permits any use, distribution, and reproduction in any medium, provided the original author(s) and the source are credited. 


\section{References}

1. Godfrey KM, Inskip HM, Hanson MA (2011) The long-term effects of prenatal development on growth and metabolism. Semin Reprod Med 29(3):257-265. doi:10.1055/s-0031-1275518

2. Thorn SR, Rozance PJ, Brown LD, Hay WW Jr (2011) The intrauterine growth restriction phenotype: fetal adaptations and potential implications for later life insulin resistance and diabetes. Semin Reprod Med 29(3):225-236. doi:10.1055/s-0031-1275516

3. Dulloo AG (2008) Thrifty energy metabolism in catch-up growth trajectories to insulin and leptin resistance. Best Pract Res Clin Endocrinol Metab 22(1):155-171. doi:10.1016/j.beem.2007.08. 001

4. Ong KK (2007) Catch-up growth in small for gestational age babies: good or bad? Curr Opin Endocrinol Diabetes Obes 14(1):30-34

5. Claris O, Beltrand J, Levy-Marchal C (2010) Consequences of intrauterine growth and early neonatal catch-up growth. Semin Perinatol 34(3):207-210. doi:10.1053/j.semperi.2010.02.005

6. Litten-Brown JC, Corson AM, Clarke L (2010) Porcine models for the metabolic syndrome, digestive and bone disorders: a general overview. Animal 4(6):899-920. doi:10.1017/ S1751731110000200

7. Swindle MM, Makin A, Herron AJ, Clubb FJ Jr, Frazier KS (2012) Swine as models in biomedical research and toxicology testing. Vet Pathol 49(2):344-356. doi:10.1177/03009858114 02846

8. Wu G, Bazer FW, Wallace JM, Spencer TE (2006) Board invited review: intrauterine growth retardation: Implications for the animal sciences. J Anim Sci 84:2316-2337

9. Lin G, Liu C, Feng C, Fan Z, Dai Z, Lai C, Li Z, Wu G, Wang J (2012) Metabolomic analysis reveals differences in umbilical vein plasma metabolites between normal and growth-restricted fetal pigs during late gestation. J Nutr 142:990-998

10. Rehfeldt C, Kuhn G (2006) Consequences of birth weight for postnatal growth performance and carcass quality in pigs as related to myogenesis. J Anim Sci 84(Suppl):E113-E123

11. Milligan BN, Fraser D, Kramer DL (2002) Within-litter birth weight variation in the domestic pig and its relation to preweaning survival, weight gain, and variation in weaning weights. Livest Prod Sci 76(1-2):181-191

12. Gondret F, Lefaucheur L, Louveau I, Lebret B (2005) The longterm influence of birth weight on muscle characteristics and eating meat quality in pigs individually reared and fed during fattening. Arch Tierz Dummerstorf 48:68-73

13. Wang X, Wu W, Lin G, Li D, Wu G, Wang J (2010) Temporal proteomic analysis reveals continuous impairment of intestinal development in neonatal piglets with intrauterine growth restriction. J Proteome Res 9(2):924-935. doi:10.1021/pr900747d

14. Chwalibog A, Touson AH, Thorbek G (2004) Energy metabolism and substrate oxidation in pigs during feeding, starvation and refeeding. J Anim Physiol Anim Nutr 88:101-112

15. Lovatto PA, Sauvant D, Noblet J, Dubois S, van Milgen J (2006) Effects of feed restriction and subsequent refeeding on energy utilization in growing pigs. J Anim Sci 84:3329-3336

16. Bruss MD, Khambatta CF, Ruby MA, Aggarwal I, Hellerstein MK (2010) Calorie restriction increases fatty acid synthesis and whole body fat oxidation rates. Am J Physiol Endocrinol Metab 298(1):E108-E116

17. Dulloo AG, Jacquet J, Montani JP (2012) How dieting makes some fatter: from a perspective of human body composition autoregulation. International Oskar Kellner Symposium on 'Metabolic flexibility in animal and human nutrition'. Proc Nutr Soc. doi:10.1017/S0029665112000225
18. Rehfeldt C, Lang IS, Görs S, Hennig U, Kalbe C, Stabenow B, Brüssow KP, Pfuhl R, Bellmann O, Nürnberg G, Otten W, Metges CC (2011) Limited and excess dietary protein during gestation affects growth and compositional traits in gilts and impairs offspring fetal growth. J Anim Sci 89(2):329-341

19. GfE (Gesellschaft für Ernährungsphysiologie, Ausschuss für Bedarfsnormen) (2006) Empfehlungen zur Energie- und Nährstoffversorgung von Schweinen (Recommendations for energy and nutrient supply of pigs). DLG-Verlag, Frankfurt am Main

20. Verband Deutscher Landwirtschaftlicher Untersuchungs- und Forschungsanstalten (2007) Die chemische Untersuchung von Futtermitteln (The chemical analysis of feed stuffs). VDLUFA Verlag Darmstadt, Methodenbuch Band III

21. Simonson DC, DeFronzo RA (1990) Indirect calorimetry: methodological and interpretative problems. Am J Physiol Endocrinol Metab 258:E399-E412

22. Dourmad JY, Sève B, Latimier B, Boisen S, Fernandez J, van der Peet-Schwering C, Jongbloed AW (1999) Nitrogen consumption, utilisation and losses in pig production in France, The Netherlands and Denmark. Livest Prod Sci 58:261-264

23. Kirchgessner M, Roth FX, Senckenberg E (1984) Einfluss einer Protein- und/oder Energierestriktion und Realimentation auf die N-Bilanz von Mastschweinen. Z Tierphysiol Tierernähr Futtermittelkd 52:173-182

24. Fabian J, Chiba LI, Frobish LT, McElhenney WH, Kuhlers DL, Nadarajah K (2004) Compensatory growth and nitrogen balance in grower-finisher pigs. J Anim Sci 82:2579-2587

25. Westerterp KR (2013) Metabolic adaptations to over- and underfeeding - still a matter of debate? Eur J Clin Nutr 67(5): 443-445. doi:10.1038/ejcn.2012.187

26. van Milgen J, Noblet J, Dubois S, Bernier JF (1997) Dynamic aspects of oxygen consumption and carbon dioxide production in swine. Br J Nutr 78:397-410

27. Biesalski K, Grimm P, Weigand-Brauner M, Biesalski U (2001) Taschenatlas der Ernährung. Georg Thieme-Verlag, Stuttgart, ISBN-10: 3131153512

28. Quiniou N, Dagorn J, Gaudré D (2002) Variation of piglets' birth weight and consequences on subsequent performance. Livest Prod Sci 78(1):63-70

29. Therkildsen M, Riis B, Karlsson A, Kristensen L, Ertbjerg P, Purslow PP, Dall M, Aaslyng M, Oksbjerg N (2002) Compensatory growth response in pigs, muscle protein turn-over and meat texture: effects of restriction/realimentation period. Anim Sci 75:367-377

30. Kristensen L, Therkildsen M, Riis B, Sørensen MT, Oksbjerg N, Purslow PP, Ertbjerg P (2002) Dietary-induced changes of muscle growth rate in pigs: effects on in vivo and postmortem muscle proteolysis and meat quality. J Anim Sci 80:2862-2871

31. Alvarenga AL, Chiarini-Garcia H, Cardeal PC, Moreira LP, Foxcroft GR, Fontes DO, Almeida FR (2013) Intra-uterine growth retardation affects birth weight and postnatal development in pigs, impairing muscle accretion, duodenal mucosa morphology and carcass traits. Reprod Fert Dev 225(2):387-395. doi:10. 1071/RD12021

32. Dulloo AG, Jacquet J, Montani JP (2002) Pathways from weight fluctuations to metabolic diseases: focus on maladaptive thermogenesis during catch-up fat. Int J Obes 26(Suppl. 2):46-57

33. Xu RJ, Mellor DJ, Birtles MJ, Reynolds GW, Simpson HV (1994) Impact of intrauterine growth retardation on the gastrointestinal tract and the pancreas in newborn pigs. J Pediatr Gastroenterol Nutr 18:231-240

34. Michiels J, De Vos M, Missotten J, Ovyn A, De Smet S, van Ginneken C (2013) Maturation of digestive function is retarded and plasma antioxidant capacity lowered in fully weaned low birth weight piglets. Br J Nutr 109(1):65-75 
35. Prince TJ, Jungst SB, Kuhlers DL (1983) Compensatory responses to short-term feed restriction during the growing period in swine. J Anim Sci 56(4):846-852

36. Derno M, Langhammer M, Renne U, Hennig U, Kuhla S, Nürnberg G, Klaus S, Brockmann GA, Metges CC (2012) Mice long-term selected for high body mass are more susceptible to body fat deposition in response to a high fat diet due to insufficient increase in heat production. Arch Tierzucht 55(6):633-646

37. Powell SE, Aberle EB (1980) Effects of birth weight on growth and carcass composition of swine. J Anim Sci 50(5):860-868

38. Gondret F, Lefaucheur L, Juin H, Louveau I, Lebret B (2006) Low birth weight is associated with enlarged muscle fiber area and impaired meat tenderness of the longissimus muscle in pigs. J Anim Sci 84:93-103

39. Larson DE, Ferraro RT, Robertson DS, Ravussin E (1995) Energy metabolism in weight-stable postobese individuals. Am J Clin Nutr 62(4):735-739

40. Labussière E, van Milgen J, de Lange CF, Noblet J (2011) Maintenance energy requirements of growing pigs and calves are influenced by feeding level. J Nutr 141(10):1855-1861

41. Leibel RL, Rosenbaum M, Hirsch J (1995) Changes in energy expenditure resulting from altered body weight. New Engl J Med 332(10):621-628

42. Ramsey JJ, Hagopian K (2006) Energy expenditure and restriction of energy intake: could energy restriction alter energy expenditure in companion animals? J Nutr 136(7):1958S-1966S

43. Koong LJ, Nienaber JA, Pekas JC, Yen JT (1982) Effects of plane of nutrition on organ size and fasting heat production in pigs. J Nutr 112:1638-1642

44. Koong LJ, Ferrell CL, Nienaber JA (1985) Assessment of interrelationships among levels of intake and production, organ size and fasting heat production in growing animals. $J$ Nutr 115(10):1383-1390

45. Chen D, Steele AD, Lindquist S, Guarente L (2005) Increase in activity during calorie restriction requires Sirt1. Science 310(5754): 1641

46. de Lange CFM, van Milgen J, Noblet J, Dubois S, Birkett S (2006) Previous feeding level influences plateau heat production following a $24 \mathrm{~h}$ fast in growing pigs. Br J Nutr 95:1082-1087
47. Bosy-Westphal A, Schautz B, Lagerpusch M, Pourhassan M, Braun W, Goele K, Heller M, Glüer CC, Müller MJ (2013) Effect of weight loss and regain on adipose tissue distribution, composition of lean mass and resting energy expenditure in young overweight and obese adults. Int J Obes (Lond). doi:10.1038/ijo. 2013.1. [Epub ahead of print]

48. Metges CC, Lehmann L, Boeuf S, Petzke KJ, Müller A, Rickert R, Franke W, Steinhart H, Nürnberg G, Klaus S (2003) Cis-9, trans-11 and trans-10, cis-12 CLA affect lipid metabolism differently in primary white and brown adipocytes of Djungarian hamsters. Lipids 38(11):1133-1142

49. van Milgen $\mathbf{J}$ (2002) Modeling biochemical aspects of energy metabolism in mammals. J Nutr 132(10):3195-3202

50. Jackman MR, Steig A, Higgins JA, Johnson GC, Fleming-Elder BK, Bessesen DH, MacLean PS (2008) Weight regain after sustained weight reduction is accompanied by suppressed oxidation of dietary fat and adipocyte hyperplasia. Am J Physiol Regul Integr Comp Physiol 294(4):R1117-R1129

51. Casirola DM, Rifkin B, Tsai W, Ferraris RP (1996) Adaptations of intestinal nutrient transport to chronic caloric restriction in mice. Am J Physiol Gastrointest Liver Physiol 271(1):G192-G200

52. Ferraris RP (1997) Effect of aging and caloric restriction on intestinal sugar and amino acid transport. Front Biosci 2:E108E115

53. Chwalibog A, Jakobsen K, Henckel S, Thorbek G (1992) Estimation of quantitative oxidation and fat retention from carbohydrate, protein and fat in growing pigs. J Anim Physiol Anim Nutr 68:123-135

54. Bruininx E, van den Borne J, van Heugten E, van Milgen J, Verstegen M, Gerrits W (2011) Oxidation of dietary stearic, oleic, and linoleic acids in growing pigs follows a biphasic pattern. J Nutr 141(9):1657-1663

55. Chwalibog A, Thorbek G (2000) Estimation of net nutrient oxidation and lipogenesis in growing pigs. Arch Anim Nutr 53(3):253-271

56. D'Souza DN, Pethick DW, Dunshea FR, Suster D, Pluske JR, Mullan BP (2004) The pattern of fat and lean muscle tissue deposition differs in the different pork primal cuts of female pigs during the finisher growth phase. Livest Prod Sci 91(1-2):1-8 